\title{
Retention of lignin in seagrasses: angiosperms that returned to the sea
}

\author{
Vincent A. Klap ${ }^{1,2, *}$, Marten A. Hemminga ${ }^{2}$, Jaap J. Boon ${ }^{1}$ \\ 'FOM Institute for Atomic and Molecular Physics, Kruislaan 407, 1098 SJ Amsterdam, The Netherlands \\ ${ }^{2}$ Netherlands Institute of Ecology, Centre of Estuarine and Coastal Ecology, Korringaweg 7, 4401 NT Yerseke, The Netherlands
}

\begin{abstract}
Using Curie-point Pyrolysis Gas Chromatography Mass Spectrometry (Py-GCMS) and Direct Temperature-resolved Mass Spectrometry (DT-MS), lignin was detected in highly purified preparations (Milled Wood Lignin = MWL) of various tissues of the seagrasses Zostera marina and Posidonia oceanica. The results indicate that $P$. oceanica contains more lignin than $Z$. marina and that roots and rhizomes generally contain more lignin than leaves. It is concluded that the ability to produce lignin is not lost by the angiosperm ancestors of extant seagrasses upon their colonization of the marine environment. Relative lignin abundances in the different tissues appear to be positively correlated with life span. It is suggested that lignification contributes to the longevity of a tissue by protecting it against microbial attack, but that deposition of lignin in seagrasses is restricted to tissues that show limited growth
\end{abstract}

KEY WORDS: Lignin - Seagrass - Pathogenic resistance - Pyrolysis - Gas chromatography · Mass spectrometry

\section{INTRODUCTION}

The presence of lignin in the plant kingdom is restricted to vascular plants. Its introduction as a plant constituent is assumed to be part of the process of adaptation to a terrestrial habitat (Sarkanen \& Ludwig 1971). The rationale behind this assumption is that land plants, in contrast to aquatic plants, need structural rigidity in order to maintain an upright position. Lignin is a 3-dimensional polymer composed of 3 different phenolic building units ( $p$-hydroxycinnamyl alcohols), which are linked to each other in various ways. After the enzymatically controlled synthesis of the monomeric building units, the final polymerization process is thought to be a random process, giving rise to a heterogeneous macromolecule without much order. Due to its 3-dimensionality, lignin does provide mechanical strength to the cell wall and thus rigidity to the plant (mainly in the transversal direction). Seagrasses evolved from terrestrial angiosperm ancestors that

-Address for correspondence: Netherlands Institute of Ecology. E-mail: klap@cemo.nioo.knaw.nl returned to the sea in the Cretaceous, $\sim 100$ million yr B.P. (Larkum \& Den Hartog 1989). Hence, they do not represent an evolutionary intermediate between primary aquatic plants and vascular land plants, but a group of vascular plants that secondarily adapted to aquatic life. One might assume that as a consequence of the return to the aquatic environment, the synthesis of lignin ceased to be essential. This redundancy would likely be reflected in a decrease in lignin content or even the complete disappearance of this cell wall constituent. At present it is not clear whether lignin is a common seagrass constituent. In their review on lignin, Lewis \& Yamamoto (1990) state that 'Evidence for lignin in submerged aquatic plants is not convincing. More definitive proof is necessary if these are to be considered lignin-synthesizing organisms'.

The uncertainty about the presence of lignin in seagrasses is mainly due to the analytical methods applied for the identification of lignin. Gravimetric analysis of residues after wet chemical treatment and histochemical staining methods provide unreliable proof for the presence of lignin, but most records in the literature are based on those methods (Lewis \& 
Yamamoto 1990). Depolymerization of the macromolecular structure (either oxidative or thermally) followed by gas chromatographic separation and mass spectrometric identification (GCMS) of the fragments has proven to be a much more reliable method for the identification of lignin (Hedges \& Mann 1979, Boon 1989). Such an approach provides detailed information on the ratio of building units and linkage types. Caution should be exercised not to assign non-lignin phenols as part of the lignin structure. Since phenolic compounds are abundant in seagrass tissues (Zapata \& McMillan 1979, Harrison 1989, Agostini et al. 1998), correction for these substances is required. This is preferably done by elimination of soluble phenols prior to analysis. Separate analysis of the soluble fraction and subtraction of this fraction from the total amount of phenolic compounds determined by oxidation or pyrolysis provides an alternative, though less accurate, correction.

Proof for the presence of lignin in seagrass as requested by Lewis \& Yamamoto (1990) was provided by Opsahl \& Benner (1993) for the species Halodule wrightii. These workers used cupric oxide oxidation (CuO) followed by GCMS with compensation for free and ester-bound phenols. H. wrightii was previously reported to be a lignin-containing species in a study which used the same method, but did not compensate for non-lignin phenols (Haddad \& Martens 1987). Reports on Zostera marina are contradictory. Using oxidative methods, Hedges \& Mann (1979) did not find any measurable amount of lignin oxidation products, whereas others did (Wilson et al. 1985, Haddad \& Martens 1987, Dovgan \& Medvedeva 1993, Dovgan et al. 1993). We are not aware of other studies of lignin in seagrasses which meet the analytical demands for unquestionable determination as expressed above.

The objective of this study was to determine if lignin is present in the seagrass species Posidonia oceanica and Zostera marina. To account for tissue-related variation, different tissues of these species were analyzed. The possible presence would allow some speculation on the physiological relevance of lignin to sea plants. For comparative purposes Fucus vesiculosus, a brown macroalga, and Spartina anglica, an angiosperm (Gramineae) from tidal salt marshes, were also included in the analyses. From an ecological point of view the results of this study might also be important because lignin is often regarded as a terrestrial tracer in the marine environment. If seagrasses contain considerable amounts of lignin, the detection of lignin in sediments or suspended organic particles in seagrass-rich regions does not necessarily indicate terrestrial run-off.

Crude plant samples were purified according to the Björkman Milled Wood Lignin (MWL) procedure
(Björkman 1956, Obst \& Kirk 1988) based on the solubility of lignin in dioxane/water. Analysis was carried out with Direct Temperature-resolved Mass Spectrometry (DT-MS) and Curie-point Pyrolysis Gas Chromatography Mass Spectrometry (Py-GCMS). Both techniques comprise thermal depolymerization of lignin into smaller fragments that are either immediately analyzed by mass spectrometry (DT-MS) or first separated by gas chromatography and then analyzed by mass spectrometry. The direct mass spectrometric analysis has the advantage that compounds with high boiling points are prevented from condensation on 'cold' surfaces, whereas Py-GCMS yields a detailed overview of the monomeric (depolimerization) products in the sample.

\section{MATERIALS AND METHODS}

Plant origin. All plant samples included in this study were collected in the SW Netherlands, except samples of Posidonia oceanica. In all cases tissues of living plants were selected. The brown alga Fucus vesiculosus was collected at the dike incline at Yerseke Harbour $\left(51^{\circ} 30^{\prime} \mathrm{N}, 4^{\circ} 04^{\prime} \mathrm{E}\right)$ situated in the Oosterschelde, a sea arm of the North Sea. Aboveground tissues of Spartina anglica were collected in the salt marsh near the village of Ellewoutsdijk ( $\left.51^{\circ} 24^{\prime} \mathrm{N}, 3^{\circ} 50^{\prime} \mathrm{E}\right), \sim 15 \mathrm{~km}$ from the mouth of the Westerschelde estuary. Permanently submerged Zostera marina plants were gathered from a seagrass meadow in the brackish Lake Veere $\left(51^{\circ} 33^{\prime} \mathrm{N}, 3^{\circ} 49^{\prime} \mathrm{E}\right)$ on 5 dates during the summer season. P. oceanica was collected from a subtidal population north of Blanes $\left(41^{\circ} 41^{\prime} \mathrm{N}, 2^{\circ} 48^{\prime} \mathrm{E}\right)$ in the Northwest Mediterranean.

MWL preparations. MWL, the lignin fraction that dissolves in dioxane/water, is generally considered as the purest lignin preparation that can be obtained (Lai \& Sarkanen 1971). Its isolation procedure was developed by Björkman (1956) and later modified by Obst \& Kirk (1988). The latter prescription has been followed here, with some small additional modifications.

The procedure involves grinding of dry plant material to pass a sieve with mesh number 50 and subsequent ball-milling for $3 \mathrm{~h}$ at $5^{\circ} \mathrm{C}$ (Retsch MM2 vibratory ball-mill with surrounding water cooling of milling chamber). The resulting powder was rinsed with Milli$Q$ water to remove inorganic salts. The desalted material was then percolated with acetone/water $(9 / 1)$ and refluxed for $7 \mathrm{~h}$ with ethanol/benzene $(2 / 1)$. Finally the residue was rinsed twice with Milli-Q water. For Fucus vesiculosus the procedure was somewhat different because the fine powder resulting from ball-milling did not allow immediate percolation. Even the material that was only subjected to the initial grinding step was 
not easily extractable. In order to reduce the jelly-like texture of this material, percolation with $0.1 \mathrm{~N} \mathrm{HCl}$ was conducted prior to percolation with acetone/water (9/1). Ball-milling was postponed till after the refluxextraction. Possible contamination of the sample with organic compounds as a result of the ball-milling treatment was counteracted by an additional acetone/water percolation afterwards.

The extractive-free material remaining after the above-mentioned procedure was suspended in dioxane/water $(24: 1, v: v)$ and stirred for $100 \mathrm{~h}$. After centrifugation of the suspension for $10 \mathrm{~min}$ at $7000 \times \mathrm{g}$ the residue was resuspended for another $100 \mathrm{~h}$ in a fresh dioxane/water mixture. The pooled supernatants were dried in a vacuum rotation film evaporator and dissolved/suspended in $96 \%$ acetic acid and subsequently added to Milli- $Q$ water such that a $-10 \%$ acetic acid solution remained. After $10 \mathrm{~min}$ centrifugation at $10000 \times g$ the pellet was dissolved/suspended in dichloromethane/ethanol (2/1). The supernatant obtained after centrifugation of this suspension ( $5 \mathrm{~min}$ at $7000 \times g)$ was added in a $1: 10(\mathrm{v}: \mathrm{v})$ ratio to dry ethylether, causing the precipitation of the dissolved purified lignin. The pellet after centrifugation $(10 \mathrm{~min}$ at $10000 \times g$ ) was dried at $50^{\circ} \mathrm{C}$ and kept in the dark at room temperature until analysis. The total yield of this procedure on a weight basis was $\sim 0.1 \%$.

Curie-point Py-GCMS. A FOM-4LX pyrolysis unit was directly coupled to a Carlo Erba 8565 HRGC gas chromatograph, which was connected via a FOM-HT interface to a JEOL DX-303 double focusing (B/E geometry) mass spectrometer. Suspensions containing aliquots of $\sim 20 \mu \mathrm{g}$ sample material were deposited on ferromagnetic wires with a Curie-point of $610^{\circ} \mathrm{C}$. Pyrolysis conditions were maintained for $6 \mathrm{~s}$ and separation of the pyrolysate was carried out with a CPSIL5-CB capillary column $(25 \mathrm{~m}$, inner diameter [i.d.] $0.32 \mathrm{~mm}$, film thickness: $0.41 \mu \mathrm{m}$ ), helium as carrier gas and a temperature program of $40(0)-6^{\circ} \mathrm{C} / \mathrm{min}$ 328(4). Compounds were ionized at $70 \mathrm{eV}$ electron impact (EI) conditions and extracted at $3 \mathrm{kV}$. Each second the mass range between (specific mass to charge ratio) 40 and $700 \mathrm{~m} / \mathrm{z}$ was scanned with a resolution of 1000. A JEOL MP-7000 system was used for data acquisition and processing

DT-MS. This analytical technique involves gradual heating of the sample in the ion-source of a mass spectrometer. Molecules (these can be intact molecules or depolimerization products) are vaporized and immediately mass analyzed. In addition to Py-GCMS, which provides a wealth of detailed information on individual pyrolysis products, DT-MS offers a less detailed chemical characterization, but due to the fact that vaporization and ionization occur at the same place, condensation of large molecules on cold spots is avoided. Therefore, dimeric and trimeric structures that often do not pass the column of the gas chromatograph can be successfully analyzed by DT-MS In principle the results obtained by DT-MS analysis offer temperature-resolved data (between 180 and $800^{\circ} \mathrm{C}$ ). However, since most organic compounds in the MWL samples investigated here depolymerized in the narrow temperature-window between 300 and $500^{\circ} \mathrm{C}$, no valuable thermal fractionation was obtained.

Compositional differences between individual samples of a sample set can be revealed by use of multivariate (factor/discriminant) analysis of mass spectral data. The essence of this method is that the major part of the variance within a set of mass spectra is described by a limited number of orthogonal functions. The weighted average spectrum of the set of spectra acts as the origin for this subspace while the orthogonal functions express the covariance of masses in the set. Projections of individual sample spectra on these functions reveal the main characteristics of the spectra compared to the origin and thus give information on the molecular composition of the samples. Details on the procedure can be found elsewhere (Hoogerbrugge et al. 1983. Windig et al. 1983, Tas 1991, Klap 1997). The utility of this approach has been demonstrated in various studies on the chemical composition of plant tissues (Boon \& Haverkamp 1982, Boon et al. 1982, Brock et al. 1985, Scheijen \& Boon 1989, Van der Hage et al. 1993, Van der Heijden \& Boon 1994, Klap et al. 1998, 1999).

The instrument used for DT-MS analysis of the samples was a double focusing (B/E geometry) JEOL SX-102 mass spectrometer equipped with a direct insertion probe. Water suspensions containing $\sim 5 \mu \mathrm{g}$ sample material were deposited on the $\mathrm{Pt} / \mathrm{Rh}$ (9/1) filament of the direct insertion probe and dried under vacuum. In the mass spectrometer an ambient source temperature of $180^{\circ} \mathrm{C}$ was maintained at a pressure of $10^{-4} \mathrm{~Pa}$. The filament current was programmed from 0 to $1.5 \mathrm{~A}$ in $90 \mathrm{~s}$, which corresponds to a heating rate of $7^{\circ} \mathrm{C} \mathrm{s}^{-1}$. The final temperature for each run was $800^{\circ} \mathrm{C}$. Ions were generated by $16 \mathrm{eV}$ EI ionization and extracted at $10 \mathrm{kV}$. The mass range $\mathrm{m} / \mathrm{z} 20$ to 400 was scanned each second at a resolution of 1000 . Data acquisition was performed on a JEOL MP-7000 system. All samples were analyzed in triplicate. Principal component (discriminant) analysis was performed on a data set of mass spectra resulting after integration of the Total Ion Current (TIC) over the time interval between 20 and $60 \mathrm{~s}$. This time interval covered almost $100 \%$ of the TIC. The software packet used for this data reduction was 'Chemometricks', a self-developed interface to MATLAB $^{\circledR}$ (The MathWorks, Natick, MA). 


\section{RESULTS}

\section{Curie-point Py-GCMS}

Curie-point Py-GCMS was performed on MWL preparations of 4 different tissues of Zostera marina (root/ rhizome, stem, leaf and spadix), 2 tissues of Posidonia oceanica (horizontal rhizome and leaf) and wholeplant tissues of Fucus vesiculosus and Spartina anglica (aboveground). The term 'stem' indicates the aboveground part of the rhizome system of $Z$. marina. This term will be used throughout in order to avoid confusion with the root/rhizome. The upper chromatogram in Fig. 1 represents the summed signal of all masses scanned of a $P$. oceanica horizontal rhizome MWL sample. Such a chromatogram is called a 'Total Ion Current trace' (TIC trace). The lower chromatogram represents the (renormalized) summed signal of a selected subset of masses of the same analysis, assigned as 'Reconstructed Ion Current trace' (RIC trace). The selected masses are $\mathrm{m} / \mathrm{z} 94,108,110,120,122,134$, $140,150,152,154,162,164,166,168$, $178,180,182,192,194,196,208,210$, $272,298,302,328,332$ and 358. These masses represent a set of commonly encountered molecular ions of pyrolysis products of lignin or lignin-like material (Boon et al. 1987, Faix et al. 1990, Pouwels \& Boon 1990, Ralph \& Hatfield 1991, Van der Hage et al. 1993).

Comparison of the TIC and RIC traces reveals that no peaks with high intensity in the TIC trace are absent in the lignin-specific RIC trace. So, lignin peaks dominate the TIC, which indicates the high purity of this lignin preparation. The fact that in many cases the relative peak intensities deviate between the 2 traces (see e.g. peaks 13 and 28 ) is due to the different degrees of fragmentation upon ionization in the mass spectrometer of the concerning molecular ions concerned. The different peak intensities in the 2 traces therefore do not affect the conclusion that Posidonia oceanica horizontal rhizome yields a clean MWL.

The peak numbers in the RIC trace refer to the compound list in Table 1. Mass spectrometric characteristics of those lignin pyrolysis products are given elsewhere (Klap 1997). The table summarizes for all 8 samples the relative peak intensities of the various compounds compared to the peak with the maximum intensity in the RIC trace. Not all samples show lignin contributions as high as Posidonia oceanica horizontal rhizome. All samples do contain phenolic $(\mathrm{P})$ compounds; however, without guaiacyl ( $\mathrm{G}=3$-methoxy-4-phenol) and syringyl $(\mathrm{S}=3,5$-dimethoxy-4-phenol) compounds
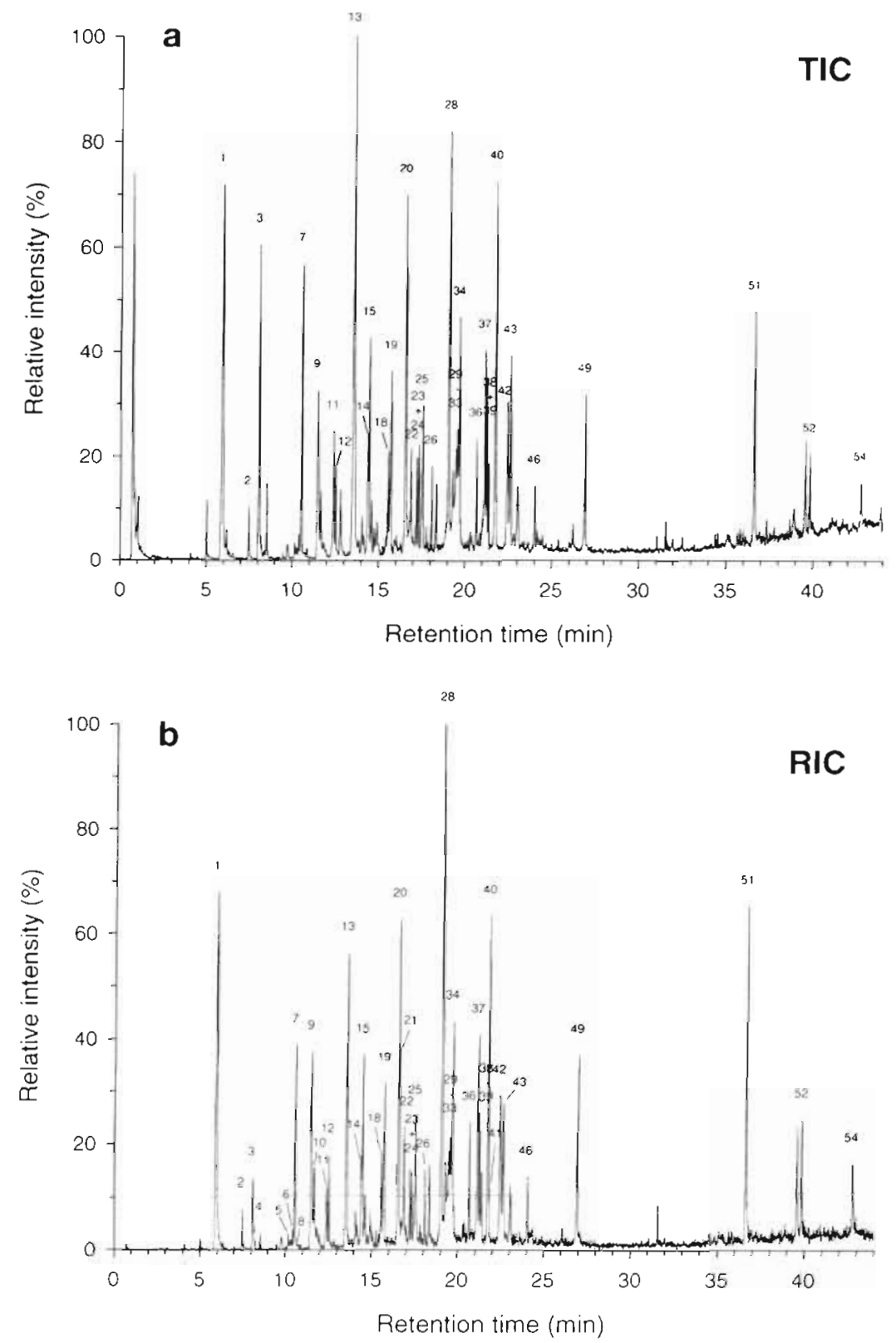

Fig. 1. (a) Total Ion Current (TIC) and (b) Reconstructed Ion Current (RIC) trace of the Milled Wood Lignin (MWL) preparation of Posidonia oceanica horizontal rhizome. The RIC represents the summed mass chromatogram of $\mathrm{m} / \mathrm{z} 94,108$, $110,120,122,134,140,150,152,154,162,164,166,168,178,180,182,192,194$, $196,208,210,272,298,302,328,332$ and 358 . The peak numbers in this figure cross-refer to those in Table 1 (first column) 
Table 1 List of identified lignin components in MWL preparations as analyzed by Curie-point Pyrolysis Gas Chromatography Mass Spectrometry (Py-GCMS). The compound numbers (first column) cross-refer to the peak numbers in Fig. 1. The letters (P), (G) and (S) after the compound names indicate phenol, guaiacyl and syringyl structures respectively. Ret. time: retention time. $M^{+}$: masses of the molecular ions of the compounds listed. F: Fucus vesiculosus, Z: Zostera marina, P: Posidonia oceanica; S: Spartina anglica; $\mathrm{l}$ : leaf; sp: spadix; $s$ : $\mathrm{stem}_{i} \mathrm{r} / \mathrm{r}$ : root/rhizome tissue; hr: horizontal rhizome. The peak intensities in the various MWL preparations are categorized according to the following indications: $M=$ maximum peak intensity in $\mathrm{RIC}_{\mathrm{C}}$ trace, $+++<100 \%$, $++<50 \%,+<10 \%, t=$ trace amount

\begin{tabular}{|c|c|c|c|c|c|c|c|c|c|c|c|}
\hline No. & Compound & Ret. time & $\mathrm{M}^{+}$ & $F$ & $z-1$ & $P-1$ & $Z$-sp & $Z$-s & $Z-\mathrm{r} / \mathrm{r}$ & $P$-hr & $S$ \\
\hline 1 & Phenol (P) & 5.9 & 94 & $\mathrm{M}$ & $M$ & M & $M$ & $\mathrm{M}$ & $M$ & +++ & ++ \\
\hline 2 & o-Methylphenol (P) & 7.45 & 108 & ++ & ++ & + & ++ & ++ & ++ & + & + \\
\hline 3 & Guaiacol (G) & 8.05 & 124 & $\mathrm{t}$ & $\mathrm{t}$ & t+ & ++ & ++ & +++ & ++ & +++ \\
\hline 4 & p-Methylphenol (P) & 8.1 & 108 & +++ & +++ & + & +++ & ++ & +++ & + & ++ \\
\hline 5 & o-Methylguaiacol (G) & 10.15 & 138 & - & - & - & - & - & - & + & + \\
\hline 6 & Ethylphenol $(\mathrm{P})$ & 10.25 & 122 & $\mathrm{t}$ & $\mathrm{t}$ & $\mathrm{t}$ & + & + & $\mathrm{t}$ & + & + \\
\hline 7 & p-Methylguaiacol (G) & 10.5 & 138 & - & - & + & - & $t$ & - & ++ & t+ \\
\hline 8 & Benzoic acid & 10.75 & 122 & $t$ & + & $\mathrm{t}$ & ++ & ++ & + & + & + \\
\hline 9 & Vinylphenol (P) & 11.45 & 120 & t+ & t++ & ++ & +++ & +t & +++ & + & +++ \\
\hline 10 & 1,2-dihydroxybenzene (P) & 11.5 & 110 & - & + & + & $t$ & t+ & +++ & t+ & ++ \\
\hline 11 & Hydroxyguaiacol (G) & 12.4 & 140 & - & - & $\mathrm{t}$ & - & - & - & ++ & + \\
\hline 12 & Ethylguaiacol $(\mathrm{G})$ & 12.5 & 152 & - & - & + & - & - & - & ++ & ++ \\
\hline 13 & Vinylguaiacol (G) & 13.55 & 150 & $\mathrm{t}$ & $\mathrm{t}$ & +++ & + & ++ & +++ & +++ & M \\
\hline 14 & Eugenol (G) & 14.35 & 164 & - & - & + & $t$ & + & + & ++ & ++ \\
\hline 15 & Syringol (S) & 14.45 & 154 & - & - & t+ & $\mathrm{t}$ & + & +++ & ++ & ++ \\
\hline 16 & Propenylphenol (P) & 14.5 & 134 & - & - & $\mathrm{t}$ & $\mathrm{t}$ & $t$ & - & $t$ & t+ \\
\hline 17 & Propylguaiacol (G) & 14.55 & 166 & - & - & $\mathrm{t}$ & - & - & - & $\mathrm{t}$ & + \\
\hline 18 & Isoeugenol (G) & 15.55 & 164 & - & - & + & $t$ & + & + & +t & ++ \\
\hline 19 & Vanillin (G) & 15.65 & 152 & - & - & ++ & $\mathrm{t}$ & + & +++ & ++ & ++ \\
\hline 20 & Methylsyringol (G) & 16.55 & 168 & - & - & $t^{+}$ & - & $\mathrm{t}$ & ++ & +++ & ++ \\
\hline 21 & Isoeugenol (G) & 16.6 & 164 & & - & t+ & $t$ & + & ++ & ++ & +++ \\
\hline 22 & Guaiacylethanal (G) & 16.85 & 166 & - & - & - & - & - & - & +t & - \\
\hline 23 & Guaiacyl $-\mathrm{C}_{3} \mathrm{H}_{3}(\mathrm{G})$ & 17.15 & 162 & - & - & $\mathrm{t}$ & - & - & - & ++ & ++ \\
\hline 24 & Guaiacyl- $\mathrm{C}_{3} \mathrm{H}_{3}(\mathrm{G})$ & 17.3 & 162 & - & - & $\mathrm{t}$ & - & - & - & $+t$ & ++ \\
\hline 25 & Acetylguaiacol (G) & 17.45 & 166 & - & - & + & $t$ & $\mathrm{t}$ & t+ & ++ & ++ \\
\hline 26 & Ethylsyringol (S) & 18.05 & 182 & - & - & - & $t$ & $\mathrm{t}$ & $\mathrm{t}$ & ++ & + \\
\hline 27 & Vanillic acid methylester (G) & 18.1 & 182 & - & - & - & $\mathrm{t}$ & $t$ & + & $\mathrm{t}$ & $\mathrm{t}$ \\
\hline 28 & Vinylsyringol (S) & 18.95 & 180 & - & - & +++ & $\mathrm{t}$ & + & +++ & $M$ & t+ \\
\hline 29 & Hydroxybenzoic acid (P) & 19.2 & 138 & - & - & - & - & - & - & + & - \\
\hline 30 & Guaiacylpropanal (G) & 19.25 & 180 & - & - & - & - & - & - & + & + \\
\hline 31 & Hydroxybenzoic acid (P) & 19.4 & 138 & - & - & - & - & - & - & + & - \\
\hline 32 & Guaiacylpropan-3-one (G) & 19.45 & 180 & - & - & - & - & - & - & + & + \\
\hline 33 & Hydroxybenzoic acid $(\mathrm{P})$ & 19.6 & 138 & - & - & - & - & - & - & + & - \\
\hline 34 & Allyl syringol (S) & 19.65 & 194 & - & - & t+ & - & + & t+ & ++ & ++ \\
\hline 35 & Propylsyringol (S) & 19.75 & 196 & - & - & $\mathrm{t}$ & - & - & - & $\mathrm{t}$ & + \\
\hline 36 & Propenylsyringol (S) & 20.65 & 194 & - & - & t+ & - & + & +t & t+ & + \\
\hline 37 & Syringaldehyde (S) & 21.15 & 182 & - & - & + & $\mathrm{t}$ & $\mathrm{t}$ & + & t+ & ++ \\
\hline 38 & Syringyl- $\mathrm{C}_{3} \mathrm{H}_{3}(\mathrm{~S})$ & 21.25 & 192 & - & - & + & - & - & $\mathrm{t}$ & + & ++ \\
\hline 39 & Syringyl- $\mathrm{C}_{3} \mathrm{H}_{3}(\mathrm{~S})$ & 21.35 & 192 & - & - & + & - & - & $t$ & + & +t \\
\hline 40 & Propenylsyringol (S) & 21.75 & 194 & - & - & t+t & - & + & +++ & +++ & ++ \\
\hline 41 & Syringylethanal (S) & 21.8 & 196 & - & - & - & - & - & + & + & - \\
\hline 42 & Acetylsyringol (S) & 22.4 & 196 & - & - & + & $\mathrm{t}$ & $\mathrm{t}$ & ++ & ++ & t \\
\hline 43 & Coniferaldehyde (G) & 22.6 & 178 & - & - & - & - & - & - & ++ & +++ \\
\hline 44 & Coniferyl alcohol (G) & 22.65 & 180 & - & - & - & $\mathrm{t}$ & - & - & $t$ & +++ \\
\hline 45 & Syringic acid methylester (S) & 23.05 & 212 & - & - & - & - & - & - & $\mathrm{t}$ & ++ \\
\hline 46 & Syringylpropan-3-one (S) & 24 & 210 & - & - & - & - & - & + & + & + \\
\hline 47 & Ferulic acid methylester (G) & 24.3 & 208 & - & - & - & - & - & - & $\mathrm{t}$ & ++ \\
\hline 48 & Unknown & 24.9 & 222 & - & - & - & - & - & - & - & t+ \\
\hline 49 & Sinapylaldehyde (S) & 26.9 & 208 & - & - & $\mathrm{t}$ & - & - & - & ++ & + \\
\hline 50 & Sinapyl alcohol (S) & 27.05 & 210 & - & - & + & - & - & - & $\mathrm{t}$ & + \\
\hline 51 & 1,2-Diguaiacylethylene $(\mathrm{G}-\mathrm{G})$ & 36.6 & 272 & - & - & + & - & $\mathrm{t}$ & + & t+ & +++ \\
\hline 52 & 1-Guaiacyl-2-syringylethylene (G-S) & 39.8 & 302 & - & - & $\mathrm{t}$ & - & - & - & + & ++ \\
\hline 53 & $\beta$-Hydroxyphenyl- $\beta$-guaiacyl-resinol (P-G) & 41.85 & 328 & - & - & - & - & - & - & - & ++ \\
\hline 54 & 1,2-Disyringylethylene (S-S) & 42.75 & 332 & - & - & $\mathrm{t}$ & - & - & - & ++ & + \\
\hline 55 & Pinoresinol (G-G) & 43.25 & 358 & - & - & - & - & - & - & - & + \\
\hline
\end{tabular}


these phenols do not indicate lignin. Fucus vesiculosus and leaf material of Zostera marina can therefore be regarded as lignin-deficient. Since the phenols in these samples are not removed during extraction with acetone/water and ethanol/benzene, it seems likely that they are present in a polymeric (e.g. tannin-like) structure.

With regard to the various tissues of Zostera marina, a trend from lignin-deficient to relatively lignin-rich is observed going from leaves via spadices and stems to roots/rhizomes. Also in Posidonia oceanica the leaves are relatively depleted in lignin compared to the horizontal rhizomes, although the leaves are not lignindeficient. With regard to the differences between species, it is clear that tissues of P. oceanica show more pronounced lignin character than the equivalent tissues of $Z$. marina. Finally, it can be deduced from Table 1 that the 2 most lignin-rich samples (Spartina anglica and $P$. oceanica horizontal rhizome) show remarkably different ratios of lignin-building units with $S$. anglica being the one relatively rich in guaiacyl structures and $P$, oceanica in syringyl structures.

\section{DT-MS}

The MWL samples discussed in the previous section were also analyzed with DT-MS. Here, all $8 \mathrm{MWL}$ samples were analyzed in triplicate and principal component (discriminant) analysis was carried out on the set of sample spectra covering practically the complete TIC signal. As described in the Materials and methods' the MWL samples in this study did not contain different fractions with distinct thermal stabilities.

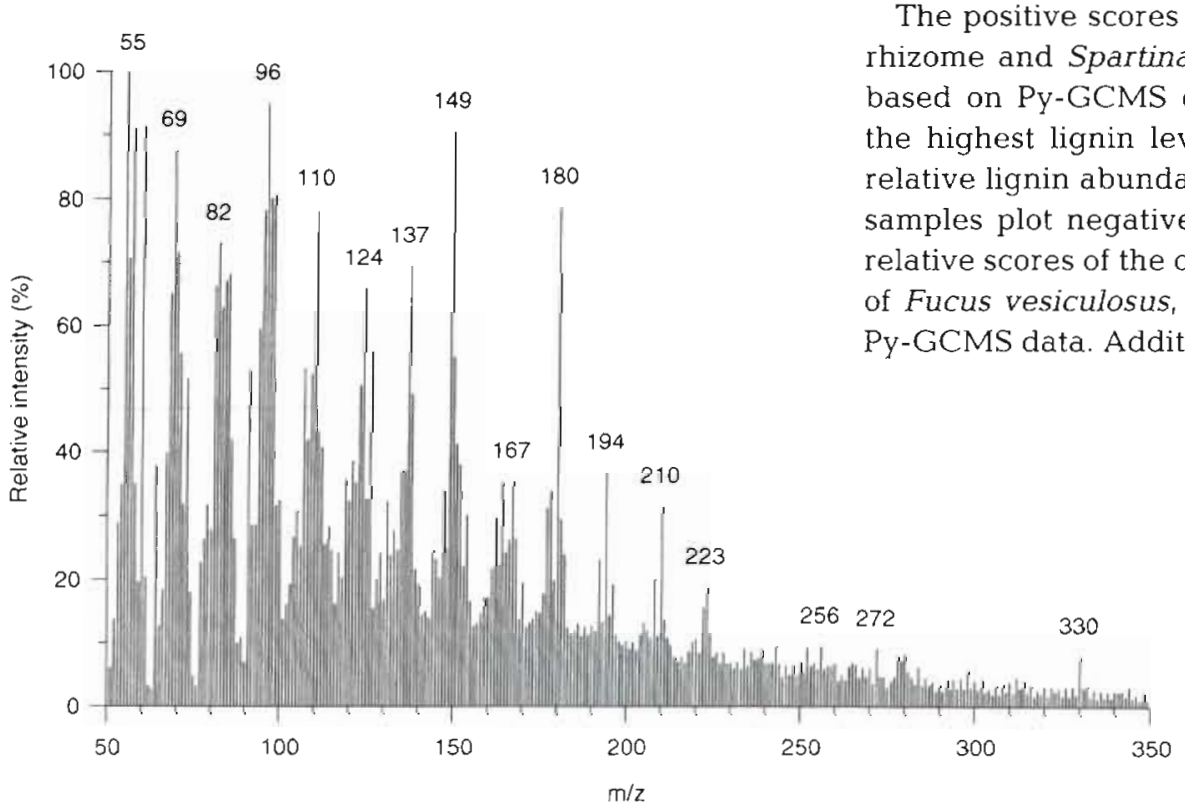

Fig. 2. Weighted average (= zeropoint) spectrum after discriminant analysis of set DT-MS spectra of all MWL samples

Fig. 2 shows the weighted average spectrum (zeropoint) of the set. The spectrum shows characteristic masses of guaiacyl (m/z 272, 180, 178, 164, 162, 150, 137 and 124) and syringyl structures $(\mathrm{m} / \mathrm{z} 210,208$, $194,192,180$ and 167). This lignin character confirms the GC-MS data. Other noticeable masses are m/z 110 and 96, assignable to furfurals that are presumably pyrolysis products of uronic acids. Other sugar markers are the masses $\mathrm{m} / \mathrm{z} 126,98$, and 85 of hexoses. The presence of these masses indicates that MWL preparations still contain some polysaccharides. $\mathrm{m} / \mathrm{z} 55,57,60$, 69 and 82 have high intensities but little significance, since they are non-characteristic and thus appear in spectra of all kind of compound classes. $\mathrm{m} / \mathrm{z} 149$, finally, can be attributed to a persistent background signal of phthalates from the laboratory atmosphere.

Mass spectral deviations from this average spectrum are addressed in Fig. 3 in which a plot of discriminant scores (Fig. 3b) is accompanied by reconstructed discriminant spectra (Fig. 3a, c). The zero-line in Fig. 3b represents the average spectrum (Fig. 2), while positive and negative scores of samples indicate increased contributions in their spectra of the upper $\mathrm{DF}^{\prime}{ }_{1}{ }^{+}$(Fig. 3a) and lower DF' ${ }_{1}^{-}$(Fig. 3b) spectrum respectively. The accents indicate that the first discriminant function (DF) has been rotated over $25^{\circ}$ in the $\mathrm{DF}_{1}-\mathrm{DF}_{3}$ plane in order to maximize lignin marker intensities in the $\mathrm{DF}_{1}{ }_{1}^{+}$ spectrum. This optimization has indeed provided a clean lignin spectrum. The $\mathrm{DF}^{\prime}{ }_{1}^{-}$spectrum does not show an equally well interpretable spectrum, although several polysaccharide markers (m/z 144, 126, 114, 98, 97 and 85) appear. Hence, this DF provides a kind of 'lignin-scale'; samples with positive scores are relatively lignin-rich while negative scores indicate ligninpoor samples.

The positive scores of Posidonia oceanica horizontal rhizome and Spartina anglica confirm the conclusion based on Py-GCMS data that these samples contain the highest lignin levels in the set. Due to the high relative lignin abundances of these 2 samples all other cosus, are also in accordance with the 
lignin abundances was obtained after DT-MS analyses of a set of Milled Wood Enzyme Lignin (MWEL) preparations. These preparations are the residues obtained after enzymatic digestion of the proteins and carbohydrates. MWEL is less pure, but it better represents the total lignin of the sample (Obst \& Kirk 1988). The results (not shown) do not provide new aspects on the composition of the various tissues, but they unambiguously confirm the above-mentioned lignin trends

The only anomalous score in Fig. $3 \mathrm{~b}$ is that of Fucus vesiculosus. Based on PyGCMS data, $F$. vesiculosus was declared lignin-deficient (together with Zostera marina leaves). Visual examination of the individual DT-MS spectra of $F$. vesiculosus supports the conclusion that this species does not contain lignin (for $Z$. marina this is less clear, but lignin markers do not clearly show up in these spectra either). Thus the following question is pertinent: why does $F$. vesiculosus, despite its lignin deficiency, have a less negative score than the lignin containing spadices and stems of $Z$. marina. The explanation for the unexpected score of $F$. vesiculosus is that its composition is not characterized by either lignin $\left(\mathrm{DF}^{\prime}{ }_{1}{ }^{+}\right.$), or polysaccharide $\left(\mathrm{DF}^{\prime}{ }_{1}\right)$. As a result, $F$. vesiculosus receives a relatively random value in the $\mathrm{DF}_{1}{ }_{1}$ score plot. Closer examination of the complete solution space reveals that the specific characteristics of $F$. vesiculosus appear in the 5th discriminant function. The accompanying reconstructed spectrum shows many peaks with high intensities, but without a pattern that relates to any known bio-organic compound class.
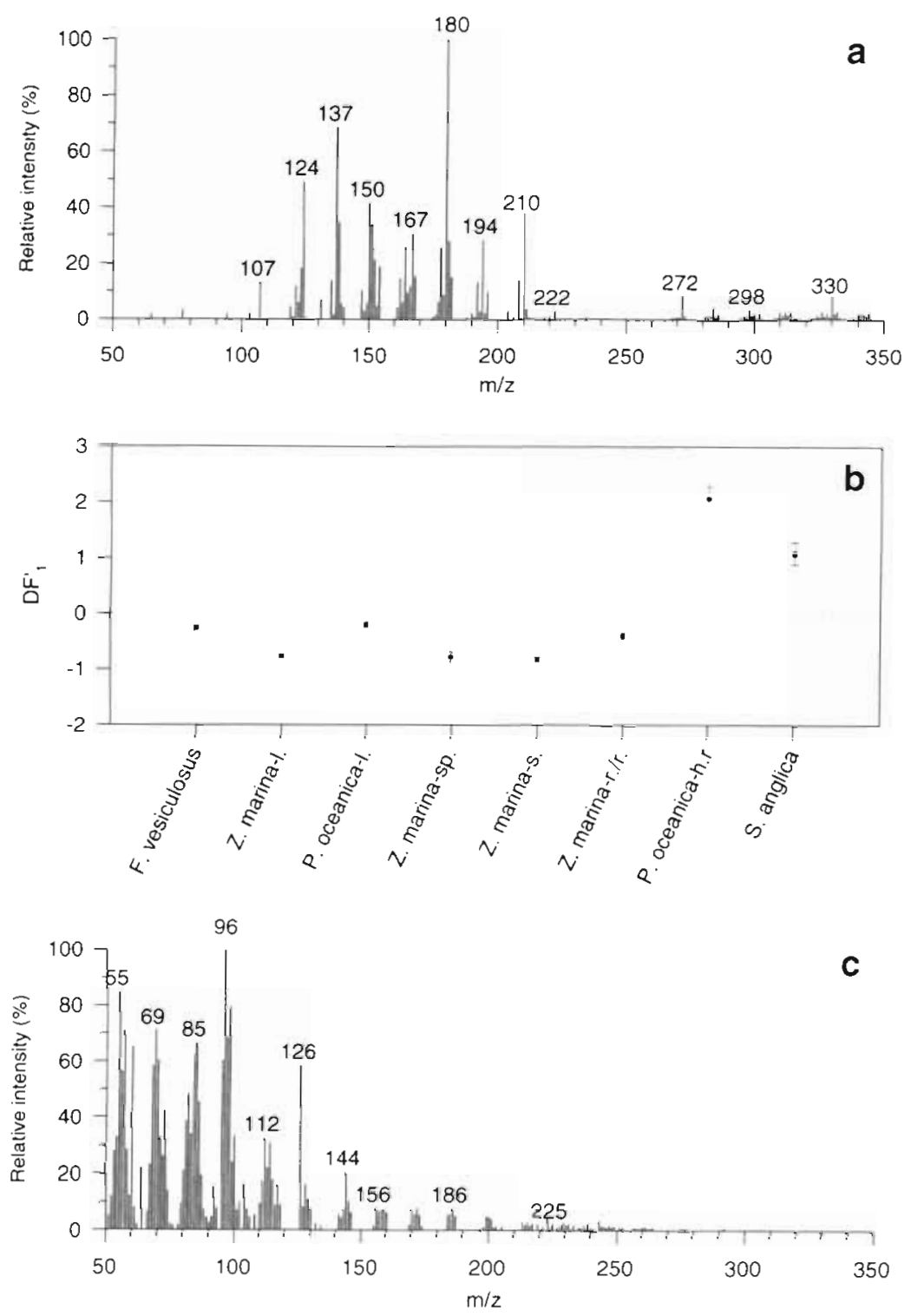

Fig. 3. (a,c) Reconstructed mass spectra and (b) score plot of first discriminant function (DF) of complete MWL sample set after rotation of $25^{\circ}$ in $\mathrm{DF}_{1}-\mathrm{DF}_{3}$ plane. The amount of variance described by this rotated DF is $41 \%$

Apart from its intrinsic chemical composition, the anomalous score of $F$. vesiculosus may also be due to chemical alterations induced by the acid treatment that was exclusively conducted on $F$. vesiculosus material to bring about the initial extraction with acetone/water. All together, however, there is no doubt that $F$. vesiculosus does not contain lignin.

The Py-GCMS data indicated that Spartina anglica was rich in guaiacyl units and poor in syringyl units, as opposed to Posidonia oceanica horizontal rhizome. This difference in lignin characteristics is perfectly reflected in the second DF (Fig. 4). In the score plot all Zostera marina and $F$. vesiculosus samples have values close to zero, while $S$. anglica and P. oceanica (both leaf

and horizontal rhizome) have high opposite scores. The accompanying reconstructed spectra predominantly bear syringyl (Fig. $4 \mathrm{a}=\mathrm{DF}_{2}{ }^{+}$) and guaiacyl markers (Fig. $4 \mathrm{C}=\mathrm{DF}_{2}^{-}$) respectively.

In a comparative study on MWL and MWEL preparations of Spartina anglica (Klap et al. 1998) it was concluded that MWL of $S$. anglica does not represent the total lignin fraction of the plant. Comparison of the MWL and MWEL preparations of the various seagrass tissues in the framework of this study (MWEL data not shown) reveals that, contrary to $S$. anglica, the MWL preparations of Zostera marina and Posido- 

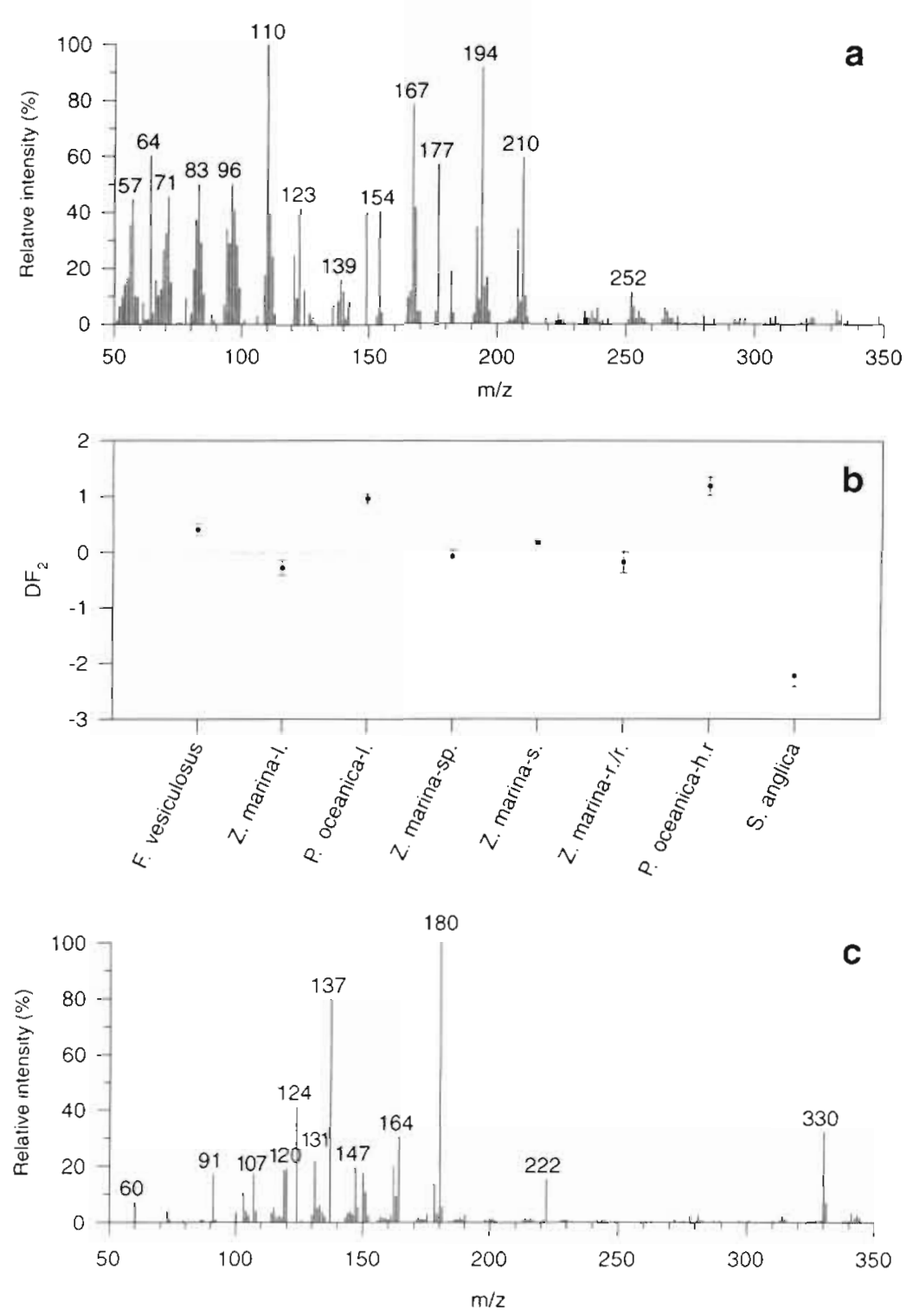

Fig. 4. (a,c) Reconstructed mass spectra and (b) score plot of second discriminant function (DF) of complete MWL sample set. The amount of variance described by this rotated $\mathrm{DF}$ is $6 \%$

nia oceanica are representative of the total lignin of the plant. An explanation for this phenomenon might be that compositional lignin fractionation over the various cell wall layers, as described by Terashima et al. (1993), is more pronounced in S. anglica than in $Z$. marina and $P$. oceanica. If the lignin of one of those layers is more susceptible to extraction by dioxane than that of the other layers, a relative enrichment with 1 specific lignin fraction (syringyl-rich) may occur in $S$. anglica. This example demonstrates the difficulty in extrapolating analytical data obtained from chemical preparations to whole tissue characterization

\section{DISCUSSION AND CONCLUSIONS}

The results of this study provide unequivocal evidence for the presence of lignin in Posidonia oceanica and Zostera marina. We also found proof for the presence of lignin in the vertical rhizomes of another seagrass, from the East African coast, Thalassodendron ciliatum. Since this observation was made on an MWEL preparation, the data are not included in this paper. Together with the identification of lignin in Halodule wrightii (Opsahl \& Benner 1993), there is now evidence for the presence of lignin in 4 of the 12 extant seagrass genera (Den Hartog 1970). It seems therefore most likely that the presence of lignin is a general feature of seagrasses. It is clear from our data, however, that substantial variation in relative abundance exists between species, $P$. oceanica having a stronger lignin character than $Z$. marina. Relative lignin abundance does not only vary with species, but also with tissue type. Roots/ rhizomes and leaves represent end members on the lignin scale (enriched and depleted respectively); stems and spadices are intermediates.

The ability to synthesize lignin is considered to be a crucial step in the evolution of terrestrial plants in order to provide rigidity to their tissue structure. It is remarkable that this feature has been retained in angiosperms that have returned to the sea, since no other marine primary producers, macroalgae included, contain lignin. Lignin is thus not essential for plant life in the sea and the question why seagrasses allocate carbon fixed in photosynthesis for the production of lignin is thus pertinent.

One answer may be that as long as lignin does not present a major disadvantage to the plant it will be retained. The synthesis of lignin, however, requires a considerable energy input. As a consequence of their submerged existence, seagrasses often have difficulty in maintaining a positive carbon balance, particularly at larger depths (Hemminga 1998). This energetic argument could have been ample reason for the cessation of lignin synthesis. The extended time period that has elapsed since the secondary adaptation of vascular plants to the marine environment ( 100 million yr) should have sufficed for the disappearance of lignin from seagrasses. Hence, we tend to believe that the 
Table 2. Relation between life span and relative (rel.) lignin abundance for the tissues analyzed in this study. The relative lignin abundances are based on the Py-GCMS data as given in Table 1 and the DT-MS data in Fig. 3. Analysis of differently purified samples (data not shown) revealed that the relative amount of lignin in. Thalassodendron ciliatum was very high

\begin{tabular}{|llcll|}
\hline Species & Tissue & $\begin{array}{c}\text { Rel. lignin } \\
\text { abundance }\end{array}$ & Life span & Source for life span data \\
\hline Zostera marina & Root/rhizome & +++ & Months to years & Own approximation \\
Zostera marina & Stem & + & Months & Own approximation \\
Zostera marina & Spadix & + & Weeks to months & Own approximation \\
Zostera marina & Leaf & - & $52 \mathrm{~d}$ & Borowitzka \& Lethbridge (1989) \\
& & & $83 \mathrm{~d}$ & Hemminga et al. (1999) \\
Posidonia oceanica & Horizontal rhizome & ++++ & $940 \mathrm{yr}$ & Boudouresque (1986) \\
Posidonia oceanica & Leaf & ++ & $\leq 5 \mathrm{yr}$ & Hemminga et al. (1999) \\
Thalassodendron ciliatum & Vertical rhizome & ++++ & & Duarte et al. (1996) \\
\hline
\end{tabular}

presence of lignin indicates that it is still a valuable constituent of seagrasses. Some possible advantages will be discussed in the following paragraphs.

A first possibility is that lignin serves the same purpose underwater as it does on land: to supply rigidity to the plant. Rigidity in seagrasses, however, may have a different significance than it has for terrestrial plants. The buoyancy of the plants implies that rigidity is not required to maintain an upright position, but rigidity is definitely needed to keep the lacunal system intact. The lacunal system consists of a continuous system of gas-filled channels that run through the plant and allow the diffusion of oxygen from the leaves to the roots (Larkum et al. 1989). Since seagrasses can live at large depths (up to $90 \mathrm{~m}$, Den Hartog 1970), the tissue layers that encompass these lacunae need to resist high pressures. Application of turgor will be one way to withstand compression, but reinforcement of the cell wall by compounds that specifically counteract transversal forces (like lignin) seems another versatile strategy.

As the lacunal system covers the whole trajectory between the roots and the leaves, the observation that seagrass leaves contain little or no lignin indicates that lignin is not a prerequisite for the strengthening of the lacunal system of seagrasses. At best it may contribute to it. But if lignin is not essential for structural strength, the question remains: what function does it have? In Table 2 it is shown that relative lignin abundance is positively correlated with the life span of the tissues analyzed, which suggests that deposition of lignin pays off with life extension of the tissue. Deposition of lignin, however, also has disadvantages. It leads to loss in elasticity of the tissue and lignification of the cell wall leads to strong but eventually dead cells (Brett \& Waldron 1990). The low relative abundance of lignin in seagrass leaves might therefore be due to the incompatibility of lignification and processes like cell growth and functioning. For several grasses such a negative correlation between relative growth rate and lignification has been observed (Niemann et al. 1992).
The correlation between life span and relative lignin abundance may be related to the presumed protective value of lignin against microbial attack. It is well recognized for land plants that lignin can only be biodegraded by a selected suite of organisms. White-rot fungi are most renowned in this respect (Chen \& Chang 1985, Harvey et al. 1987. Hedges et al. 1988, Goni et al. 1993), but bacteria have also been reported as lignin decomposers (Amer \& Drew 1980, Benner et al. 1984). Lignin synthesis by land plants has been observed as a direct response to microbial infection or physical wounding (Matern et al. 1995, Hawkins \& Boudet 1996. Dushnicky et al. 1998). Other phenolic compounds that commonly occur in seagrasses are believed to have comparable antibiotic properties (Zapata \& McMillan 1979, Harrison 1982, Buchsbaum et al 1990, Agostini et al. 1998). Increased levels of these compounds in leaves of Zostera marina have been observed as a response to pathogenic infection (Vergeer \& Develi 1997). It would be an interesting scope for further research to find out whether these compounds act as non-rigid substitutes for lignin and are produced in higher quantities in the leaves compared to tissues with higher longevity.

The detection of lignin in seagrasses also has an implication for marine ecological studies where lignin is used as a land-derived marker. In areas where seagrass densities are high the use of lignin as a terrestrial tracer does not seem appropriate.

Acknowledgements. We acknowledge Dr Miguel-Angel Mateo for kindly providing the Posidonia oceanica samples and Ko Verschuure for collecting the Zostera marina samples. Liz Minor and Pauline Kamermans are thanked for their valuable comments on the original manuscript.

\section{LITERATURE CITED}

Agostini S, Desjobert JM, Pergent G (1998) Distribution of phenolic compounds in the seagrass Posidonia oceanica. Phytochemistry 48:611-617 
Amer GI, Drew SW (1980) Microbiology of lignin degradation. In: Tsao GT, Flickinger MC, Finn RK (eds) Annual reports on fermentation processes. Academic Press, Inc, New York, p 67-103

Benner R, Newell SY, Maccubbin AE, Hodson RE (1984) Relative contributions of bacteria and fungi to rates of degradation of lignocellulosic detritus in salt-marsh sediments. Appl Environ Microbiol 48:36-40

Björkman A (1956) Studies on finely divided wood-extraction of lignin with neutral solvents. Sven Papperstidn 59: $477-485$

Boon JJ (1989) An introduction to pyrolysis mass spectrometry of lignocellulosic material; case studies on Barley straw, corn stem and Agropyron. In: Chesson A, Orskov ER (eds) Physico-chemical characterisation of plant residues for industrial and feed use. Elsevier Applied Science, London, p 25-49

Boon JJ, Haverkamp J (1982) Pyrolysis mass spectrometry of intact and decomposed leaves of Nuphar variegatum and Zostera marina, and some archeological eelgrass samples. Hydrobiol Bull 16:71-82

Boon JJ, Wetzel RG, Godshalk GL (1982) Pyrolysis mass spectrometry of some Scippus species and their decomposition products. Limnol Oceanogr 27:839-848

Boon JJ, Pouwels AD, Eijkel GB (1987) Pyrolysis high resolution gas chromatography mass spectrometry studies on beech wood: capillary high resolution mass spectrometry of a beech lignin fraction. Biochem Soc Trans 15:170-174

Borowitzka MA, Lethbridge RC (1989) Seagrass epiphytes. In: Larkum AWD, McComb AJ, Shepherd SA (eds) Biology of seagrasses. Elsevier, Amsterdam, p 686-722

Boudouresque CF (1986) Longevité des rhizomes de Posidonia oceanica. Trav Sci Parc Nat Region. Rés Nat Corse 2: $12-13$

Brett C, Waldron K (1990) Physiology and biochemistry of plant cell walls. Unwin Hyman, London

Brock TCM, Boon JJ, Paffen BGP (1985) The effects of the season and of the water chemistry on the decomposition of Nymphaea alba L. weight loss and pyrolysis mass spectrometry of the particulate matter. Aquat Bot 22:197-229

Buchsbaum RN, Short FT, Cheney DP (1990) Phenolic-nitrogen interactions in eelgrass. Zostera marina L.: possible implications for disease resistance. Aquat Bot 37:291-297

Chen CL, Chang HM (1985) Chemistry of lignin biodegradation. In: Higuchi $T$ (ed) Biosynthesis and biodegradation of wood components. Academic Press, London, p 535-556

Den Hartog C (1970) The sea-grasses of the world. NorthHolland Publishing Company, Amsterdam

Dovgan IV, Medvedeva EI (1993) Studies of algae and seagrasses lignins. Khim Drevesiny 1-3:82-100

Dovgan IV, Ozolina NR, Medvedeva EI (1993) Studies of algae and sea-grasses lignins. Khim Drevesiny 1-3:47-54

Duarte CM, Hemminga MA, Marbà N (1996) Growth and population dynamics of Thalassodendron ciliatum in a Kenyan back-reef lagoon. Aquat Bot 55:1-11

Dushnicky LG, Ballance GM, Sumner MJ, Macgregor AW (1998) The role of lignification as a resistance mechanism in wheat to a toxin-producing isolate of Pyrenophora triticirepentis, Can J Plant Pathol 20:35-47

Faix O, Meier D, Fortmann I (1990) Thermal degradation products of wood. A collection of electron-impact (EI) mass spectra of monomeric lignin derived products. Holz Roh-Werkstoff 48:351-354

Goñi MA, Nelson B, Blanchette RA, Hedges JI (1993) Fungal degradation of wood lignins: geochemical perspectives from CuO-derived phenolic dimers and monomers. Geochim Cosmochim Acta 57:3985-4002
Haddad RI, Martens CS (1987) Biochemical cycling in an organic-rich marine basin: 9. Sources and accumulation rates of vascular plant-derived organic material. Geochim Cosmochim Acta 51:2991-3001

Harrison PG (1982) Control of microbial growth and of amphipod grazing by water-soluble compounds from leaves of Zostera marina. Mar Biol 67:225-230

Harrison PG (1989) Detrital processing in seagrass systems: a review of factors affecting decay rates, remineralization and detritivory. Aquat Bot 23:263-288

Harvey PJ, Schoemaker HE, Palmer JM (1987) Lignin degradation by white rot fungi. Plant Cell Environ 10:709-714

Hawkins S, Boudet A (1996) Wound-induced lignin and suberin deposition in a woody angiosperm (Eucalyptus gunnii hook): histochemistry of early changes in young plants. Protoplasma 191:96-104

Hedges JI, Mann DC (1979) The characterization of plant tissues by their lignin oxidation products. Geochim Cosmochim Acta 43:1803-1807

Hedges JI, Blanchette RA, Weliky K, Devol AH (1988) Effects of fungal degradation on the CuO oxidation products of lignin: a controlled laboratory study. Geochim Cosmochim Acta 52:2717-2726

Hemminga MA (1998) The root/rhizome system of seagrasses: an asset and a burden. J Sea Res 39:183-196

Hemminga MA, Marbà N, Stapel J (1999) Leaf nutrient resorption, leaf lifespan and the retention of nutrients in seagrass systems. Aquat Bot 65:141-158

Hoogerbrugge R, Willig SJ, Kistemaker PG (1983) Discriminant analysis by double stage principal component analysis. Anal Chem 55:1710-1712

Klap VA (1997) Biogeochemical aspects of salt marsh exchange processes in the SW Netherlands. PhD thesis, University of Amsterdam

Klap VA, Boon JJ, Hemminga MA, Van Soelen J (1998) Chemical characterization of lignin preparations of Spartina anglica by pyrolysis mass spectrometry. Org Geochem 28 $707-727$

Klap VA, Louchouarn P, Boon JJ, Hemminga MA, Van Soelen J (1999) Decomposition dynamics of six salt marsh halophytes as determined by cupric oxide oxidation and direct temperature-resolved mass spectrometry. Limnol Oceanogr 44(6): $1458-1476$

Lai YZ, Sarkanen KV (1971) Isolation and structural studies. In: Sarkanen KV, Ludwig CH (eds) Lignins; occurrence, formation, structure and reactions. Wiley \& Sons, Inc, New York, p 165-240

Larkum AWD, Den Hartog C (1989) Evolution and biogeography of seagrasses. In: Larkum AWD, McComb AJ, Shepherd SA (eds) Biology of seagrasses. Aquatic Plant Studies. Elsevier, Amsterdam, p 112-156

Larkum AWD, Roberts G, Kuo J, Strother S (1989) Gaseous movements in seagrasses. In: Larkum AWD, McComb AJ, Shepherd SA (eds) Biology of seagrasses. Aquatic Plant Studies. Elesevier, Amsterdam, p 686-722

Lewis NG, Yamamoto E (1990) Lignin: occurrence, biogenesis and biodegradation. Annu Rev Plant Physiol Plant Mol Biol 41:455-496

Matern U. Grimmig B, Kneusel RE (1995) Plant cell wall reinforcement in the disease-resistance response: molecular composition and regulation. Can J Bot 73:511-51.7

Niemann GJ, Pureveen JBM, Eijkel GB, Poorter H, Boon JJ (1992) Differences in relative growth rate in 11 grasses correlate with differences in chemical composition as determined by pyrolysis mass spectrometry. Oecologia 89: $567-573$

Obst JR, Kirk TK (1988) Isolation of lignin. In: Wood WA, 
Kellogg ST (eds) Methods in enzymology. Biomass, Part b: lignin, pectin and chitin). Academic Press, New York, p 1-11

Opsahl S, Benner R (1993) Decomposition of senescent blades of the seagrass Halodule wrightii in a subtropical lagoon. Mar Ecol Prog Ser 94:191-205

Pouwels AD, Boon JJ (1990) Analysis of beech wood samples, its milled wood lignin and polysaccharide fractions by Curie-point and platinum filament pyrolysis-mass spectrometry. J Anal Appl Pyrol 17:97-126

Ralph J, Hatfield RD (1991) Pyrolysis-GC-MS characterization of forage materials. J Agric Food Chem 39:1426-1437

Sarkanen KV, Ludwig CH (1971) Lignins; occurrence, formation, structure and reactions. John Wiley \& Sons, Inc, New York

Scheijen MA, Boon JJ (1989) Characterization of tobacco lignin preparations by Curie-point pyrolysis-mass spectrometry and Curie-point pyrolysis-high resolution gas chromatography/mass spectrometry. J Anal Appl Pyrol 15:97-120

Tas AC (1991) Mass spectrometric fingerprinting: soft ionization and pattern recognition. $\mathrm{PhD}$ thesis, University of Leiden

Terashima N, Fukushima K, He L, Takabe K (1993) Comprehensive model of the lignified plant cell wall. In: Jung HG,

Editorial responsibility: Otto Kinne (Editor),

Oldendorf/Luhe, Germany
Buxton DR, Hatfield RD, Ralph J (eds) Forage cell wall structure and digestibility. American Society of Agronomy, Inc, Madison, WI, p 247-270

Van der Hage ERE, Mulder MM, Boon JJ (1993) Structural characterization of lignin polymers by temperature-resolved in-source pyrolysis-mass spectrometry and Curiepoint pyrolysis-gas chromatography/mass spectrometry. J Anal Appl Pyrol 25:149-183

Van der Heijden E, Boon JJ (1994) A combined pyrolysis mass spectrometric and light microscopic study of peatified Calluna wood from raised bog peat deposits. Org Geochem 22:903-919

Vergeer LHT, Develi A (1997) Phenolic acids in healthy and infected leaves of Zostera marina and their growth-limiting properties towards Labyrinthula zosterae. Aquat Bot 58:65-72

Wilson JO, Valiela I, Swain T (1985) Sources and concentrations of vascular plant material in sediments of Buzzards Bay, Massachusetts, USA. Mar Biol 90:129-137

Windig W, Haverkamp J, Kistemaker PG (1983) Interpretation of sets of pyrolysis mass spectra by discriminant analysis and graphical rotation. Anal Chem 55:81-88

Zapata O, McMillan C (1979) Phenolic acids in seagrasses. Aquat Bot $7: 307-317$

Submitted: June 10, 1999; Accepted: September 10, 1999 Proofs received from author(s): March 2, 2000 